\title{
Aplikasi Belajar Berbasis Digital Dapat Meningkatkan Motivasi Belajar Mahasiswa
}

\author{
Bintang Narpati ${ }^{1}$, Milda Handayani ${ }^{2}$, Eri Bukhari ${ }^{3}$ \\ Universitas Bhayangkara Jakarta Raya \\ b.narpati@gmail.com ${ }^{1}$, milda.handayani@ubharajaya.ac.id ${ }^{2}$, eri_bukhari@yahoo.com ${ }^{3}$
}

\section{ARTICLE INFO}

Keywords

digital applications, smartphones, motivation

\begin{abstract}
$A B S T R A C T$
The purpose of this study is to measure how the role of digital based learning applications through smartphone facilities can influence learning motivation among students. The method used in this study was to use quantitative descriptive analysis involving 90 (ninety) students using random sampling techniques.

This method of collecting data through a questionnaire method supported by the documentation method. Linear regression analysis is a technique used in analyzing this data. Based on the results of this study concluded: (1) There is a significant influence between digitalbased learning applications on student learning motivation (2) There is a significant influence between smartphones on student learning motivation (3) There is a significant influence between digital based learning applications and smartphone against student learning motivation. Simultaneously with the presence of digital-based learning applications and through smartphone means can increase student learning motivation
\end{abstract}

\section{A. Pendahuluan}

1. Analisis Situasi

Revolusi Industri 4.0 mendorong setiap industri menggunkan aplikasi - aplikasi baru berbasis digital dalam memudahkan kegiatan operasionalnya sehari - hari. Tidak hanya industri besar saja yang akan melakukan aplikasi digital dalam kegiatan operasionalnya namun juga merambah ke industri menengah, kecil bahkan perorangan untuk dapat memanfaatkan apalikasi berbasis digital ini. Aplikasi berbasis digital, pelajar, mahasiswa, ibu rumah tangga, pensiunan bahkan anak - anak pun memanfaatkan teknologi berbasis apolikasi diital ini melalui sarana smartphone.

Penggunaan aplikasi berbasis digital melalui smartphone umumya banyak digunakan dalam transaksi kehidupan sehari - hari. Sebagai contoh bila aplikasi berbasis digital ataupun mahasiswa ingin berangkat ke kantor atau ke kampus, mereka hanya menggunakan aplikasi transportasi misalnya gojek ataupun grab untuk sampai di tempat tujuannya. Selain untuk menghindari kemacetan juga untuk menghemat tenaga bagi yang menggunakannya.

2. Permasalahan Mitra

Dalam belajarpun, mahasiswa terkadang sulit menerima pemahaman - pemahaman ataupun tugas - tugas yang diberikan oleh dosennya. Untuk mengatasi hal ini sebagian mahasiswa menggunakan belajar kelompok ataupun yang indvidu membuka laptop membrowsing mesin penjelajah atau google dan tidak sedikit pula yang menggunakan smartphone sebagai alat yang membantu dalam mengatasi kesulitan pembelajaran.

Namun apakah dengan smartphone melalui aplikasi digitalnya dapat membantu memotivasi mahasiswa untuk lebih giat melakukan pembelajaran atau malah sebaliknya bahkan malas untuk belajar karena mungkin dengan aplikasi dalam smartphone tidak dapat membantu pemecahan masalah yang dihadapi. Mungkin mereka lebih senang bertatap muka ataupun diskusi dengan teman - teman kuliahnya ataupun dengan melakukan bimbingan private dengan dosen lainnya. Dalam belajar, seringkali pelajar maupun mahasiswa sering terkendala dalam menerima ilmu yang telah disampaikan oleh guru maupun dosennya sehingga mereka menggunakan aplikasi belajar digital yang ada di smartphone untuk membantu mengatasi kesulitannya. 
3. Solusi Yang Ditawarkan

Melalui aplikasi berbasis digital dalam smartphone diharapkan dapat membantu para mahasiswa dalam meningkatkan motivasi belajarnya yang selama ini ada beberapa mahasiswa yang terkendala dalam pemahaman mata kuliah tertentu. Aplikasi berbasis digital ini merupakan aplikasi dalam menjawab soal - soal yang sering diujikan baik dalam ujian tengah semester maupun ujian akhir semester disertai dengan latihan - latihannya.

\section{Target Luaran}

Target luaran dari kegiatan ini adalah terciptanya aplikasi berbasis digital untuk mata kuliah tertentu yang dapat membantu mahasiswa dalam melakukan proses belajar dan dapat meningkatkan motivasi belajarnya.

\section{B. Pelaksanaan Dan Metode Kegiatan}

1. Pelaksanaan:

a) Lokasi dan waktu

Lokasi kegiatan ini adalah Universitas " $\mathrm{X}$ " di wilayah kotamadya Bekasi dan waktu pelaksanaannya adalah bulan Oktober sampai dengan Nopember 2018.

b) Latar belakang peserta

Peserta merupakan mahasiswa tingkat 2 dan 3 pada universitas tersebut terdiri dari mahsiswa pria dan wanita.

c) Jumlah peserta

Jumlah responden yang diikutkan dalam kegiatan ini sebanyak 90 (Sembilan puluh) mahasiswa.

\section{Metode dan Materi Kegiatan}

Metode dalam kegiatan ini adalah pendampingan dalam penggunaan aplikasi dalam smartphone untuk mata kuliah tertentu yang sering menjadi kendala pemahaman bagi mahasiswa khususnya mata kuliah yang bersifat menghitung seperti statistika, matematika, akuntansi dan lain - lain.

Metode dalam penelitian yang digunakan adalah analisa deskriptif kuantitatif. Metode pengumpulan data dilakukan dengan kuesioner yang disebarkan dan melakukan wawancara dengan beberapa perwakilan mahasiswa. Saat ini penggunaan smartphone dalam kegiatan sehari - hari sudah sering digunakan baik dari anak - anak sampai usia dewasa. Namun dalam penggunaannya sebagian orang ada yang menggunakannya untuk membantu dalam kegiatan sehari - hari seperti belajar, transportasi, pinjaman dan laian - lain dan tidak sedikit pula smartphone digunakan untuk bermain game ataupun menonton film dan sebagainya. Aplikasi yang ada dismartphone ada yang sangat membantu da nada pula yang digunakan hanya untuk meluangkan waktu santai saja, tergantung dari niat pengguna smartphone (gambar 1).

Gambar 1. Kerangka Penelitian

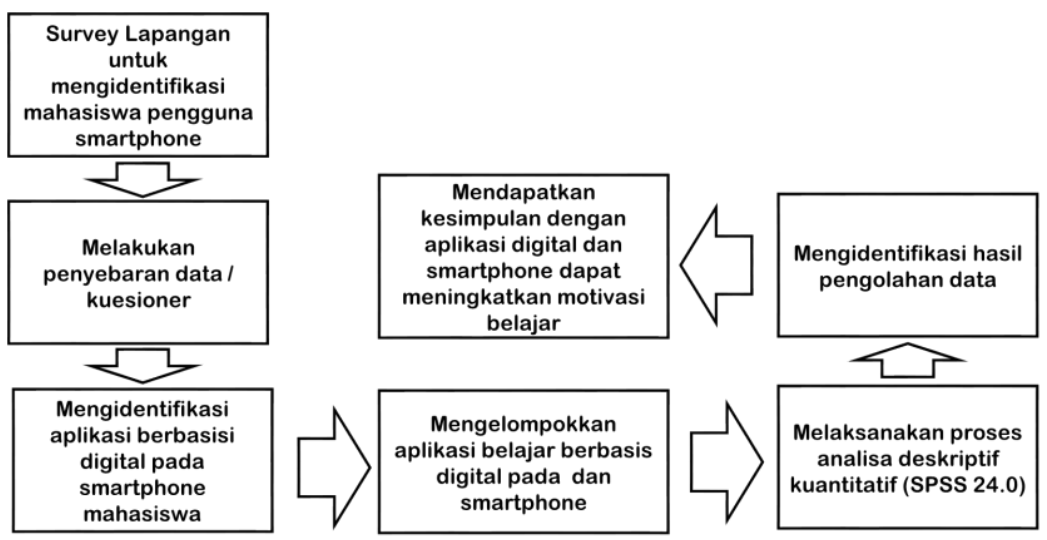


Dari asumsi di atas bahwa penggunaan aplikasi berbasis digital dengan media smartphone dapat membantu mahasiswa dalam membantu pelajaran di tempat kuliah. Para mahasiswa sering mnggunakan smartphone dibandingkan dengan laptop atau komputer karena smartphone yang ringkas dibawa kemana- mana dan dapat memuat aplikasi digital sesuai kebutuhan mahasiswa.

Gambar 2.

Hubungan antara Aplikasi Berbasis Digital dan Smartphone terhadap Motivasi Beloajar Mahasiswa

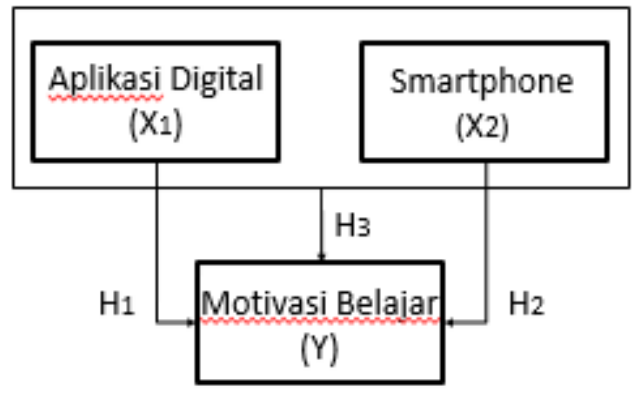

Pada (gambar 2.) menjelaskan Hipotesis dengan perumusan :

1. $\mathrm{H}_{1}$ : Apakah ada pengaruh secara signifikan antara Aplikasi Berbasis Digital terhadap Motivasi Belajar Mahasiswa?

2. $\mathrm{H}_{2}$ : Apakah ada pengaruh secara signifikan antara menjadi penggunaan Smartphone terhadap Motivasi Belajar Mahasiswa?

3. $\mathrm{H}_{3}$ : Apakah ada pengaruh secara signifikan antara Aplikasi Berbasis Digital dan penggunaan Smartphone terhadap Motivasi Belajar Mahasiswa?

\section{LANDASAN TEORI}

\section{Aplikasi Digital}

Instruksi dari komputer yang mengolah input menjadi output itulah yang dinamakan aplikasi (Jogiyanto, 2005). Kamus Besar Bahasa Indonesia online menyebutkan aplikasi adalah implementasi dari perancangan sistem yang mengolah data dengan menggunakan ketentuan bahasa pemrograman tertentu. Aplikasi merupakan program komputer yang diciptakan dengan tujuan untuk mengerjakan tugas khusus yang mendapat perintah dari pengguna. Menurut (Bates, 1995) Kesejahteraan ekonomi dapat diwujudkan melalui teknologi dengan pemanfaatan secara bijak dengan meningkatkan kualitasnya.

Kata Digital berarti jari jemari yang atau Digitus/bahasa Yunani (Wikipedia, n.d.). Sebagai contoh apabila kita menghitung jari jemari orang dewasa, maka jumlahnya adalah sepuluh. Jumlah sepuluh tersebut terdiri dari 2 radix, yaitu angka 1 dan 0, oleh sebab itu konsep Semua sistem dalam komputer dalam operasionalnya menggunakan sistem digital yang meruapakan basis datanya atau dikenal dengan istilah Bit (Binary Digit).

Kesimpulan tersebut bahwa aplikasi digital berupa instruksi (instruction) yang mengolah dengan bahasa pemrograman sehingga komputer dapat memproses input menjadi output.

\section{Smartphone}

Telepon seluler cerdas atau biasa disebut smartphone adalah suatu alat berupa telepon yang dapat digenggan yang memiliki kemampuan melalui pengunaan dan fungsinya menyerupai komputer. Fitur lain dari smartphone adalah mampu menambah aplikasi - aplikasi baru yang dipasang dalam smartphone tersebut (Zaki : 2008). Sehingga dapat disimpulkan smartphone merupakan telepon seluler yang mempunyai kemampuan seperti komputer dan dapat ditambah dengan aplikasi - aplikasi tertentu. Smartphone merupakan telepon selular dengan komponen tertentu seperti memori, mikroprosesor, modem dan layar (Williams, B.K., dan Sawyer, 2011). Smartphone dapat pula menunjang keperluan lainnya. Dengan memiliki multifungsi, smartphone juga dapat digunakan untuk keperluan bisnis (Ferdiana, Ridi, ST, 2008). 
Smartphone atau telepon cerdas yang dilengkapi dengan komponen seperti komputer dapat memudahkan bagi penggunanya untuk dibawa kemana - kemana dengan hanya mengenggam saja dan digunakan untuk keperluan, komunikasi dan bisnis.

\section{Motivasi}

Menurut (Siagian, 2014), motivasi adalah dorongan, atau keaktifan yang menggerakkan seseorang dan mengarahkan perilaku, sikap dan tindak tanduk seseorang yang selalu dikaitkan dengan pencapaian tujuan organisasi. Motivasi adalah interaksi dari seseorang terhadap situasi yang mendukungnya. Dengan situasi yang berbeda tersebut maka dorongan untuk melaksanakan sesuatu tergantung pada waktu yang teppat pula.

Sedangkan, menurut (Sedarmayanti, 2011) upaya seseorang untuk dengan kemapuannya untuk mencapai tujuan organisasi dan memenuhi kebutuhan individual. Seseorang yang termotivasi maka akan bertekad untuk melaksanakan keinginannya untuk mencapai tujuan organisasi dengan cara - cara yang dilakukan oleh masing - masing individu.

Secara kesimpulan, bahwa motivasi merupakan perilaku yang bertujuan mencapai tujuan organiasi melalui komitmen. Menurut (Wibowo, 2011), dimensi dan indikator motivasi Kebutuhan untuk berprestasi, Kebutuhan memperluas pergaulan, Kebutuhan untuk menguasai sesuatu pekerjaan,

\section{Hasil Dan Pembahasan}

Teknik analisis data dilakukan dengan cara mengumpulkan data dengan penyebaran kuesioner dan didukung metode dokumentasi. Teknik atau metode analisis yang digunakan adalah teknik analisis regresi linier ganda. Metode analisis data ini menggunakan SPSS (Statistical Package for the Social Science) for windows versi 24.0 sebagai berikut:

\section{a. Uji Kualitas Data}

1. Uji Validitas Instrument

Uji validitas terhadap 2 variabel bebas yaitu aplikasi berbasis digital dan smartphone dan variabel terikat Motivasi belajar diperoleh $r$ _hitung > $r_{-}$tabel yaitu di atas nilai 0,207 sehiingga kuesiner dikatakan valid.

2. Uji Reliabilitas

Uji Reliabilitas menunjukkan variabel bebas dan terikat memiliki nilai Cronbach Alpha > r_tabel $(0,207)$ sehingga variabel bebas maupun terikat dikatakan reliabel.

\section{b. Uji Asumsi Klasik}

Sebelum data di analisis, ada beberapa asumsi yang harus terpenuhi untuk dapat diteruskan dalam pengujian hipotesis. Uji persyaratan dalam analisis ini :

\section{Uji Normalitas}

Melihat dari normal probability plot dapat diketahui pola distribusi mendekati normal karena titik-titik mengikuti garis lurus ke arah diagonal sehingga model regresi ini layak dalam asumsi normalitas (gambar 2.)

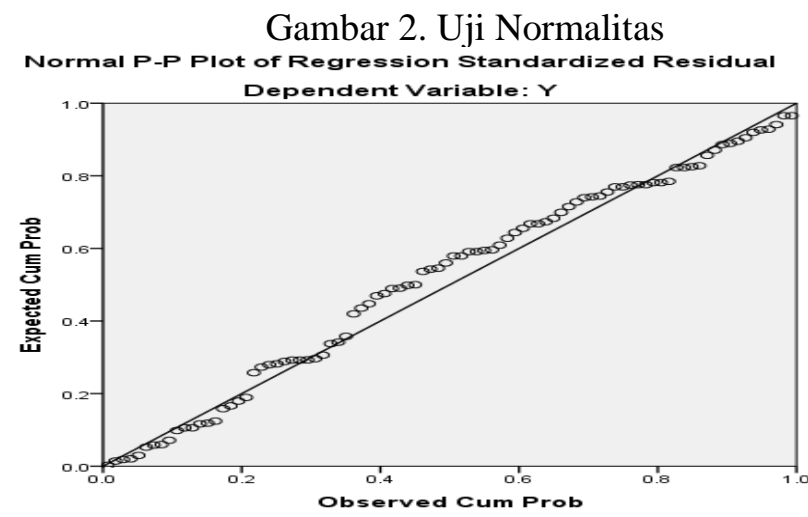


2. Uji Multikolonieritas

Uji Multikolonieritas adalah pengujian untuk mengetahui ada tidaknya kolerasi yang sgnifikan antar variabel-varabel independen dalam model regresi linier berganda. (Imam Ghozali 2012). Nilai Tolerance sebesar 0,410 > 0,10 dan nilai VIF 2,439 < 10. Dari hasil uji multikolinieritas pada uji ini tidak ditemukan multikolinieritas

3. Uji Heteroskedasitas

Hasil uji Heteroskedastisitas menunjukkan adanya penyebaran titik-titik data baik di atas dan dibawah ataupun disekitar angka 0 dan titik - titik tidak membentuk pola (gambar 3.)

Gambar 3. Uji Heteroskedastisitas

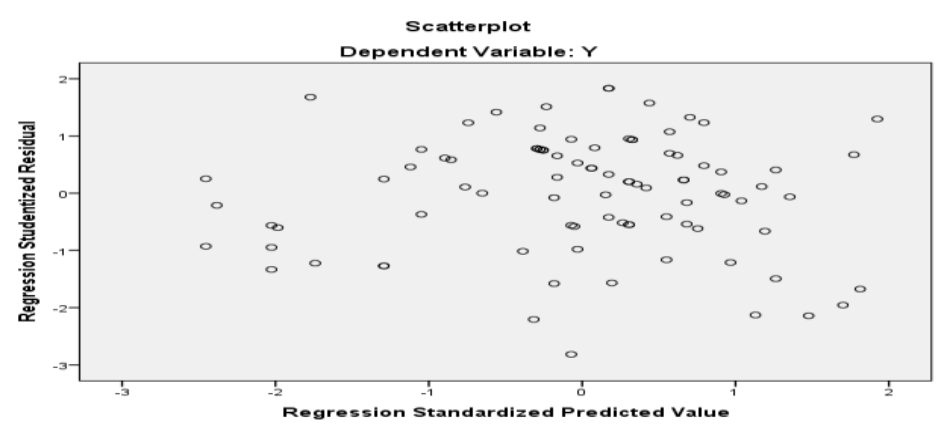

4. Uji Autokorelasi

Metode ini menggunakan Durbin Watson (DW). Nilai DW adalah 2,241 sehingga 1,7026 < $2,241<2,5974$, maka tidak terjadi autokorelasi.

\section{c. Analisis Linier Berganda}

Memiliki persamaan regresi linier bergandanya yaitu :

$\mathrm{Y}=11,052+0,341 \mathrm{X}_{1}+0,288 \mathrm{X}_{2}$

Dimana:

Y = Motivasi belajar,

$11,052 \quad=$ Konstanta

0,341 dan $0,288=$ Koefisien regresi

$\mathrm{X}_{1} \quad=$ Aplikasi berbasis digital

$\mathrm{X}_{2} \quad$ Smartphone

Dari penelitian yang dilakukan terhadap para Mahasiswa Universitas " $X$ " di kotamadya Bekasi, didapatkan hasil sebagai berikut :

Penelitian yang berjudul "Aplikasi Belajar Berbasis Digital Dapat Meningkatkan Motivasi Belajar Mahasiswa" ini menggunakan dua variabel bebas dan satu variabel terikat. Dua variabel bebas tersebut yaitu Aplikasi berbasis digital dan Smartphone sedangkan variabel terikat adalah Motivasi belajar. Guna mengungkapkan data yang ada dan untuk membuktikan hipotesis yang telah dikemukakan, maka dalam pengumpulan data dengan menggunakan angket. Berdasarkan data responden diperoleh persamaan regresi, $\mathrm{Y}=11,052+0,341 \mathrm{X}_{1}+0,288 \mathrm{X}_{2}$. Konstanta sebesar 11,052 menyatakan, bahwa jika tidak ada pengaruh antara aplikasi berbasis digital atau Smartphone maka besarnya Motivasi belajar adalah 11,052. Koefisien regresi $X_{1}=0,341$ menyatakan bahwa setiap terjadi peningkatan satu unit penggunaan aplikasi berbasis digital maka akan meningkatkan Motivasi belajar sebesar 0,341 . Koefisien regresi $\mathrm{X}_{2}=0,288$ menyatakan bahwa setiap terjadi peningkatan satu unit penggunaan Smartphone maka akan meningkatkan motivasi belajar sebesar 0,288 .

Hasil penghitungan model summary, R Square sebesar 0,486. Hal ini berarti 48,6 \% Motivasi belajar dapat dijelaskan oleh kedua variabel tersebut. Sedangkan sisanya 51,4\% atau $(100 \%$ $48,6 \%$ ) adalah variabel lain yang tidak ada dalam penelitian ini.

a. Pengujian Hipotesis I 
Berdasarkan hasil perhitungan dengan menggunakan uji t, diperoleh nilai t-hitung variabel penggunaan aplikasi berbasis digital (X1) sebesar 3,278 dengan taraf signifikansi 0,05 dan t-tabel yaitu 1,987. Karena nilai t-hitung > ttabel $(3,278>1,987)$ maka Ho ditolak, artinya secara parsial ada pengaruh positif yang signifikan antara penggunaan aplikasi berbasis digital terhadap motivasi belajar.

b. Pengujian Hipotesis II

Berdasarkan hasil perhitungan dengan menggunakan uji t, diperoleh nilai t-hitung variabel penggunaan smartphone (X2) sebesar 2,890 dengan taraf signifikansi 0,05 dan t-tabel yaitu 1,987. Karena nilai t-hitung > t-tabel $(2,890>1,987)$ maka Ho ditolak, artinya secara parsial ada pengaruh positif yang signifikan antara penggunaan smartphone terhadap Motivasi belajar.

c. Pengujian Hipotesis III

Berdasarkan hasil perhitungan dengan menggunakan uji F, diperoleh nilai F-hitung sebesar 41,052 dengan taraf signifikansi 0,05 dan F-tabel sebesar 3,100. Karena nilai F-hitung > F-tabel $(41,052>3,100)$ maka Ho ditolak, artinya ada pengaruh yang signifikan antara penggunaan aplikasi berbasis digital dan penggunaan smartphone terhadap Motivasi belajar.

Besaran kontribusi/pengaruh dari kedua variabel bebas yaitu aplikasi berbasis digital (X1) dan Smartphone (X2) yang diamati terhadap variabel terikat Motivasi belajar (Y) yang dinyatakan dengan nilai $\mathrm{R}$ Square atau koefisien determinasi R Square (R2) didapat nilai sebesar 0,486. Nilai tersebut memberikan makna bahwa kontribusi/pengaruh dari kedua variabel bebas yaitu aplikasi berbasis digital (X1) dan Smartphone (X2) adalah 48,6\%, sedangkan sisanya 51,4\% adalah kontribusi/pengaruh dari variabel bebas lainnya yang tidak diamati dalam penelitian ini.

Pengaruh variabel bebas yang tidak diteliti dalam penelitian ini antara lain penggunaan laptop atau komputer, diskusi kelompok ataupun belajar private, peranan dosen dalam mengajar.

\section{Penutup}

\section{Kesimpulan}

Dari hasil penelitian ini dapat dijelaskan :

1. Berdasarkan uji t, aplikasi berbasis digital (X1) mendapatkan hasil yaitu nilai t-hitung $>\mathrm{t}$-tabel. Dengan demikian hipotesis-I yang menyatakan bahwa "Ada pengaruh positif yang signifikan antara penggunaan aplikasi berbasis digital terhadap Motivasi belajar mahasiswa" diterima atau terbukti kebenarannya.

2. Berdasarkan uji t, Smartphone (X2) mendapatkan hasil bahwa nilai t-hitung lebih besar dari ttabel. Dengan demikian hipotesis-II yang menyatakan bahwa "Ada pengaruh positif yang signifikan antara penggunaan smartphone terhadap Motivasi belajar mahasiswa" diterima atau terbukti kebenarannya.

3. Dari uji regresi linier ganda antara penggunaan aplikasi berbasis digital (X1) dan smartphone (X2) terhadap Motivasi belajar (Y) diperoleh bahwa nilai F-hitung > F-tabel. Dengan demikian hipotesis-III yang menyatakan bahwa "Ada pengaruh positif yang signifikan antara penggunaan aplikasi berbasis digital dan smartphone terhadap Motivasi belajar mahasiswa secara simultan" diterima atau terbukti kebenarannya.

4. Hasil dari uji hipotesis di atas menunjukkan bahwa penggunaan aplikasi berbasis digital dengan media smartphone membantu para mahasiswa dalam menyelesaikan tugas perkuliahan dan lebih memahami materi yang disampaikan oleh dosen pada saat perkuliahan sehingga dapat meningkatkan motivasi belajar mahasiswa.

\section{Saran}

Sebaiknya perguruan tinggi ataupun lembaga - lembaga terkait dalam bidang pendidikan dapat mengadakan perlombaan dengan tema menciptakan aplikasi berbasis digital dalam rangka pengayaan aplikasi dan membantu mahasiswa dalam proses belajar.

\section{Daftar Pustaka}

Bates, A. W. (1995). Technology, Open Learning and Distance Education. London: Routledge.

Ferdiana, Ridi, ST, M. (2008). Membangun Aplikasi SmartClient Pada Platform Windows Mobile. 
Jakarta: PT Elex Media Komputindo.

Jogiyanto, H. M. (2005). Analisa dan Desain Sistem Informasi: Pendekatan Terstruktur Teori dan Praktik Aplikasi Bisnis. Ypgyakarta: ANDI.

Sedarmayanti. (2011). Tata Kerja dan Produktifitas Kerja. Bandung: Mandar Maju.

Siagian, S. P. (2014). Manajemen Sumber Daya Manusia. Jakarta: Bumi Aksara.

Wibowo. (2011). Manajemen Kinerja. Jakarta: Raja Grafindo Persada.

Wikipedia. (n.d.). Digital. Retrieved from https://id.wikipedia.org/wiki/Digital

Williams, B.K., dan Sawyer, S. . (2011). Using Information Technology: A Practical Introduction to Computer \& Communications (6th ed). New York: McGraw Hill. 